\title{
肺癌臨床病期分類の問題点
}

\section{Some Problems in practice of clinical stage classification of Japan Lung Cancer Society.}

本間日臣 ${ }^{*} \cdot$ 田村昌士 ${ }^{*} \cdot$ 渡 一功 ${ }^{*} \cdot$ 佐川圭助 ${ }^{*} \cdot$ 稲富恵子 ${ }^{*} \cdot$ 吉良技郎 ${ }^{* *}$ 石川創二 ${ }^{* * *}$. 野辺地篤郎 ${ }^{* * *}$. 谷本普一 $* * * *$. 正木幹雄

\footnotetext{
抄録：原発性肺癌の臨床病期を決定するに際して注意すべき点を検討した。すなわち切除また は試験開胸例計108例を対象に, 胸部X線所見による術前判定と開胸時判定の対比を行い, 両者の一致率, 過大評価, 過少評価の実態を調查検討した結果, 最も判定を誤り易い病 期がII期であった。その理由の第 1 は肺門及び縦隔リンパ節への転移の有無の推定のむ ずかしさであることをのべた。このことは TNM分類の $\mathrm{N}_{1}, \mathrm{~N}_{2}$ の判定についてもあては まると考える。
}

\section{はじめに}

原発性肺癌の治療計画, 切除適応の判定, 治 療の効果，予後の比較を同じ背景因子の下で論 じ，研究者間の情報交換を容易にするために日 本肺癌学会が肺癌の組織型分類と臨床病期分類 とを採択してから10年余経過した。本分類は， その簡便さの故にわが国では広く用いられてい る. 最近日米協力の下に TNM 方式による病期分 類がつくられつ、あるが，これが既に10年前か ら用いられている臨床病期分類とほとんど同じ ものとなりつ、あることは本分類がすぐれてい ることを証明するものであろう。しかし本分類 のみで切除の適応を決定することは十分でない. 組織型と大きさ（扁平上皮癌を除く）とを考慮 に入れなければならない。本分類は表 1 の如く になっている。すなわち I 期は主病変が肺内に

$\begin{array}{ll}* & \text { 順天堂大学内科 (呼吸器) } \\ * * & \text { 自治医科大学呼吸器内科 } \\ * * * & \text { 順天堂大学胸部外科 } \\ * * * * & \text { 聖路加国際病院放射線科 } \\ * * * * * & \text { 虎の門病院呼吸器科 } \\ * * * * * * & \text { 虎の門病院胸部外科 }\end{array}$

限局し，しかも全く転移のみられないもの，II 期は転移が肺門リンパ節にとどまる場合で，い まだ縦隔リンパ節まで及んでいないもの，III期 は隣接病変のみで遠隔転移がないもの, すなわ ち縦隔リンパ節, 肋骨, 心膜, 横隔膜に波及の あるもの，IV 期は鎖骨上窩リンパ節を含め遠隔 転移のあるものである。血行転移の発生を意味 し隣接病変の有無に関係しない. 対側肺への波 及は遠隔転移とみなして IV 期に入れる。

さて，本分類を用いるに際して最もむずかし いのは, 肺門および縦隔リンパ節転移有無の判 読である。すべての例に縦隔鏡を行なうことは 出来ず, X 線正面像, 側面像, 断層像などから 推定することになるが, 開胸してみると術前の 推定と異なることが多い. 今回われわれは切除 または試験開胸例を対象に，術前判定による胸 部 X 線所見と開胸時所見との対比を行い, 術前 判定による病期と開胸時の肉眼所見に基づく確 定病期との一致率, 過大評価, 過小評価の実態 を調查し，病期決定に際して留意すべき点を検 討したので報告する。 


\section{対象および研究方法}

順天堂大学呼吸器内科, 同胸部外科, 虎の門 病院呼吸器内科, 聖口力病院胸部外科に入院し, 当初手術適応ありと判定した試験開胸または切 除施行例108例である。いずれも開胸により肺門 部, 縦隔リンパ節および胸壁への進展の有無を 肉眼的に確認した。組織型は腺癌51例, 扁平上 皮癌38例，未分化癌19例である.

術前の病期の判定は前後方向, 側面方向の胸 部X線写真および断層写真について, 肺癌症例 の胸部 X 線写真読影に習熟した複数の医師が判 定を下し，合議のもとに病期を決定した。

開胸時の肉眼所見は順大胸部外科石川，虎の 門病院胸部外科正木の記載による。判定時期か ら手術までに要した日時は 1 例の80日を除き， 7 日から 52 日の間で平均 20 日であった。

\section{成 綘}

全症例についての成績を一括して表示したの が表 2 である。縦軸は開胸前の臨床病期で $T$ は 総計を示す。横軸の病期は開胸所見にもとずき 修正された病期である。

本表中, 左上から右下に向う対角線上に並ぶ 数字は術前, 術後の所見が一致した症例数で, I 期 18例， II 期10例，III 期 25例，IV 期 5 例， す なわち108例中58例 (53.7\%)であった。術前 I 期 と判定され，術後II 期に修正された症例は 6 例, III 期に修正された症例は 9 例，IV 期に修正され たものは 1 例である。

術前の II 期判定がIII 期，IV 期と術後修正され たものはそれぞれ13名および 2 名である。また 術前の III 期が IV 期に修正された症例は 4 例ある. これらの対角線より右上の症例は実際の病変の 進展よりも胸部X線所見が過小に判定 (underestimate)された症例を意味する。

前述の対角線の下に位置する症例についてみ ると, 術前 II 期中の 8 例は I 期に, 術前 III 期中 の 5 例は I 期に， 1 例は II 期へ，さらに術前 IV 期症例中の 1 例がIII 期へと術後修正されている. これら症例は実際の病変の拡がりに比し, 胸部 X線所見を過大に評価 (overestimate)したこと を意味する。過小評価および過大評価率はそれ
ぞれ32.4率, $13.9 \%$ で実際の病変の拡がりを過 小に評価しやすい傾向があることを示唆する。 正当な評価が下された症例は III 期, IV 期と病期 の進展とともに $71.4,83.3 \%$ と増加するが, こ れは胸郭内での進展が広汎となる点から当然予 测される成績である。これに次ぐ一致率は I 期 群で, II 期群の一致率が $30.3 \%$ と最も低い。こ れは II 期症例の約40\%がIII 期へと術後修正され， I 期症例の 6 例が II 期へ， 9 例が III 期へと修正 されていることと一致し，肺門部リンパ節への 転移, 縦隔りンパ節への転移が胸部 X 線写真で 過少に評価されていること，むしろこれら所見 の胸部X線での読影に限界があることを示して いる. 術前 I 期の症例中の 1 例, II 期の 2 例, III 期の 4 例がそれぞれ IV 期に修正されているが, これは同側他葉へのX線上不可視的な血行性転 の存在が手術的に発見されたことを意味しこ れら病変の検出も, 肺門, 縦隔リンパ節への転 移の検出と同様困難であることを示している.

次に末梢型 (peripheral type) と肺門型 (hilar type)とに分けて見ると, 表 $3 ， 4$ から明らかな ように，適正な評価が下されたものは末梢型で $59.3 \%$, 肺門型で37\%と，末梢型の方が肺門型 より正しく評価された率が高い。一方過小評価 率は肺門型で $44.4 \%$ ，末梢型で $28.4 \%$ と肺門型 で過小評価率が高い。これも肺門，縦隔への進 展の判定が困難なことを裏付ける成績である。

組織型別にみて末梢型の多い腺癌末梢型 (表5) と肺門型の多い扁平上皮癌肺門型(表 6 ) に分け てみても適正な評価を得たものは腺癌末梢型で $60 \%$, 扁平上皮癌肺門型で $43.8 \%$ と同じ傾向の 成績を得た。

\section{考 案}

本調查成績は肺癌症例の胸部 X 線所見読影で もっとも難かしい点は, 肺門, 縦隔リンパ節転 移の有無の判定であることを示している.

このことは日本肺癌学会の臨床病期分類のみ でなくTNM分類の応用にあたっても， $\mathrm{N}_{1}$ か $\mathrm{N}_{2}$ かの判定に際し同じ難かしさに当面することを 指摘出来る.つまり両分類とも共通の問題点を 持つといえる。胸部 X線写真上に明らかに認め 
Table 1. Clinical Stage Classification of Pulmonary Cancer - Japan Joint Commitee -

\begin{tabular}{|c|c|c|c|c|c|c|}
\hline \multirow{4}{*}{$\begin{array}{l}\text { Clinical } \\
\text { Stage }\end{array}$} & \multicolumn{4}{|c|}{ Chest X-Ray Findings } & \multirow{4}{*}{$\begin{array}{c}\text { Distant } \\
\text { Metastases }\end{array}$} & \multirow{4}{*}{$\begin{array}{c}\text { TNM System } \\
\text { UICC }\end{array}$} \\
\hline & \multirow{3}{*}{$\begin{array}{c}\text { Primary } \\
\text { Lesion }\end{array}$} & \multicolumn{3}{|c|}{ Intrathoracic Metastases } & & \\
\hline & & \multicolumn{2}{|c|}{ Lymph Nodes } & \multirow{2}{*}{$\begin{array}{c}\text { Mediastinum, } \\
\text { Pleura, Ribs, } \\
\text { Pericardium, } \\
\text { Diaphragm }\end{array}$} & & \\
\hline & & $\begin{array}{l}\text { Hilar } \\
\text { Lymph } \\
\text { Nodes }\end{array}$ & $\begin{array}{l}\text { Mediastinal } \\
\text { Lymph } \\
\text { Nodes }\end{array}$ & & & \\
\hline I & + or - & - & - & - & - & $\begin{array}{l}\text { T0 T2, } \\
\text { N0, M0 }\end{array}$ \\
\hline II & + or - & + & - & - & - & $\begin{array}{l}\mathrm{T} 0 \sim \mathrm{T} 2, \\
\mathrm{~N} 1, \mathrm{M} 0\end{array}$ \\
\hline III & + or - & + or - & + & + & - & $\begin{array}{l}\mathrm{T} 0 \sim \mathrm{T} 3, \\
\mathrm{~N} 2, \mathrm{M} 0\end{array}$ \\
\hline IV & + or - & + or - & + or - & + or - & + & $\begin{array}{l}\mathrm{T} 0 \sim \mathrm{T} 3 \\
\quad \mathrm{~N} 0 \sim \mathrm{N} 2, \mathrm{M} 1\end{array}$ \\
\hline
\end{tabular}

Table 2. Comparison of pre- and post thoracotomy staging on 108 cases

\begin{tabular}{|c|c|c|c|c|c|}
\hline $\begin{array}{c}\text { ope } \\
\mathrm{x}-\mathrm{p}\end{array}$ & I & II & III & IV & $\mathrm{T}$ \\
\hline I & $\begin{array}{c}18 \\
(52.9 \%)\end{array}$ & 6 & 9 & 1 & $\begin{array}{c}34 \\
31.5 \%\end{array}$ \\
\hline II & 8 & 10 & 13 & 2 & $\begin{array}{c}33 \\
30.6 \%\end{array}$ \\
\hline III & 5 & 1 & 25 & 4 & $\begin{array}{c}35 \\
(30.3 \%)\end{array}$ \\
\hline IV & 0 & 0 & 1 & 4 & 6 \\
\hline T & 31 & 17 & 48 & 6 \\
$(8.7 \%$ & $15.7 \%$ & $44.4 \%$ & $11.1 \%$ & $10.6 \%$ \\
\hline
\end{tabular}
$\mathrm{U} ; \quad 35 / 108 ; \quad 32.4 \%$
a 51 cases
A; $58 / 108 ; 53.7 \%$
p 38 cases
O; $15 / 108 ; 13.9 \%$
k 19 cases

$\mathrm{U}$ : underestimated $\mathrm{A}$ : adequate $\mathrm{O}$ : overestimated a: Adenoca. p: Epidermic ca.

$\mathrm{k}$ : Undifferentiated ca.

られる程度の大きさなら判定は容易であるが, 手術は不可能となる。この限界にいどむ方法と して ${ }^{67} \mathrm{Ga}$ シンチ, 縦隔鏡, CT スキャン等があげ られる。しかし ${ }^{67} \mathrm{Ga}$ シンチには癌特異性のない 点で問題があり，縦隔鏡は侵襲が大きく一般的
Table 3. Comparison of pre- and post thoracotomy staging on 81 cases of peripheral type

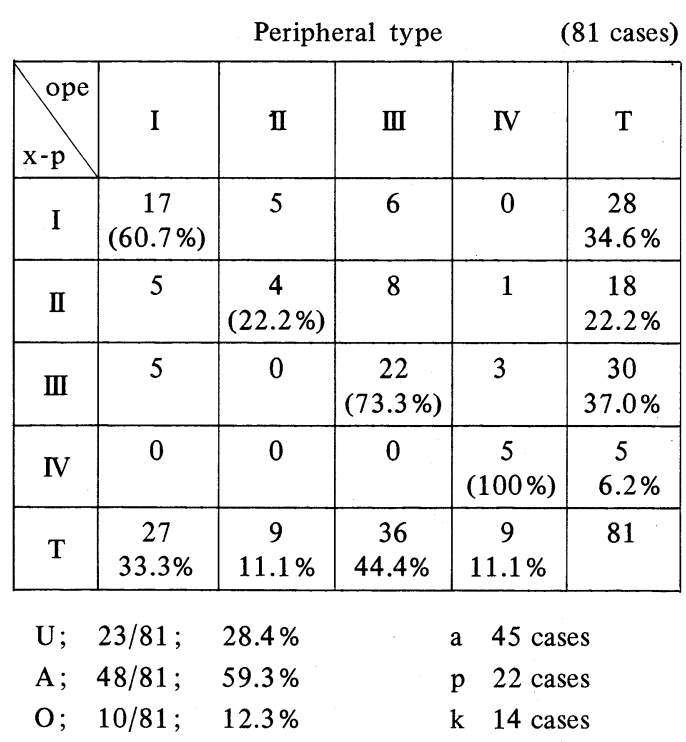

ではなく，CTスキャンは今後に期待をつなぐ段 階である。

以上臨床病期分類を活用するに際して最も判 定を誤り易い病期がII期であり，その理由の第 1 が分岐部抢よび縦隔リンパ節への転移の有無 
Table 4. Comparison of pre- and post thoractomy staging on 27 cases of hilar type

Hilar type

(27 cases)

\begin{tabular}{|c|c|c|c|c|c|}
\hline $\begin{array}{c}\text { ope } \\
\text { x-p }\end{array}$ & I & II & III & IV & T \\
\hline I & $\begin{array}{c}1 \\
(16.7 \%)\end{array}$ & 1 & 3 & 1 & $\begin{array}{c}6 \\
22.2 \%\end{array}$ \\
\hline II & 3 & 6 & 5 & 1 & $\begin{array}{c}15 \\
(40.0 \%)\end{array}$ \\
\hline III & 0 & 1 & 3 & 1 & $\begin{array}{c}5 \\
(60.0 \%)\end{array}$ \\
\hline IV & 0 & 0 & 1 & 0 & $\begin{array}{c}1 \\
3.7 \%\end{array}$ \\
\hline T & 4 & 8 & 12 & 3 & 27 \\
\hline
\end{tabular}

$\mathrm{U} ; \quad 12 / 27 ; \quad 44.4 \%$

$\begin{array}{ll}\text { a } & 6 \text { cases } \\ \text { p } & 16 \text { cases } \\ \text { k } & 5 \text { cases }\end{array}$

A; $10 / 27 ; 37.0 \%$

O; $5 / 27 ; 18.5 \%$

k 5 cases

の排定のむずかしさであり，第 2 が縦隔または 胸膜への波及の推定のむずかしさであることを 述べた。発生部位からみれば肺門型 $\mathrm{I}$ 期の判定 が末梢型 I 期のそれよりむずかしく, 組織型か らみれば，扁平上皮癌 I 期の判定が腺癌のそれ よりむずかしいことになる。

このむずかしさは，TNM分類の $\mathrm{N}_{1}$ および $\mathrm{N}_{2}$ の判定についても同様で，この 2 つの分類は判 定に関して共通の問題点を持つといえょう。本 病期分類応用に当って念頭におくべき問題点で あり，将来この問題解決のための方法の開発を 期待したい。
Table 5. Comparison of pre- and post thoracotomy staging on 45 cases of adeno-peripheral type

\begin{tabular}{|c|c|c|c|c|}
\multicolumn{4}{|c|}{ A-peripheral } & (45 cases) \\
\hline ope & I & II & III & IV \\
\hline I & 10 & 3 & 3 & 0 \\
\hline II & 1 & 1 & 4 & 1 \\
\hline III & 4 & 0 & 12 & 2 \\
\hline IV & 0 & 0 & 0 & 4 \\
\hline
\end{tabular}

$\mathrm{U} ; \quad 13 / 45 ; \quad 28.9 \%$

A; $27 / 45 ; \quad 60.0 \%$

O; $5 / 45 ; \quad 11.1 \%$

Table 6. Comparison of pre- and post thoracotomy staging on 16 cases of epidermo-hilar type

\begin{tabular}{|c|c|c|c|c|}
\hline ope & I & II & III & IV \\
\hline I & 1 & 1 & 1 & 1 \\
\hline II & 2 & 4 & 1 & 1 \\
\hline III & 0 & 1 & 2 & 0 \\
\hline IV & 0 & 0 & 1 & 0 \\
\hline
\end{tabular}

$\mathrm{U} ; \quad 5 / 16 ; \quad 31.25 \%$

A; $7 / 16 ; \quad 43.75 \%$

O; $4 / 16 ; 25.0 \%$ 


\title{
Some Problems in practice of clinical stage classification of Japan Lung Cancer Society
}

\author{
H. Homma*, M. Tamura*, K. Watanabe*, K. Sagawa*, \\ K. Inatomi*, S. Kira**, S. Ishikawa***, T. Nobezi****, \\ S. Tanimoto***** and M. Masaki******
}

\author{
* Division of Respiratory Disease, Department of Internal Medicine \\ School of Medicine Juntendo University, Tokyo \\ ** Division of Respiratory Disease, Department of Internal Medicine, \\ Jichi Medical School, Tochigi-Ken \\ *** Department of Chest Surgery, School of Medicine Juntendo University \\ **** Department of Radiology, St. Luke's International Hospital, Tokyo \\ ***** Chest Clinic Toranomon General Hospital, Tokyo \\ ****** Department of Chest Surgery, Toranomon General Hospital, Tokyo
}

The purpose of this study is to evaluate the adequacy of roentgenologycally determined stages in patients with pulmonary cancer. The clinical stage classification of the Japan Lung Cancer Society was used. And pre and post thoracotomy stages were compared in 108 cases.

The results revealed that only 58 cases among 108 cases $(53.7 \%)$ were diagnosed adequately. The cause of misjudges mostly derived from the difficulty to differentiate whether lymph nodes in the hilum and in the mediastinum were involved or not. 